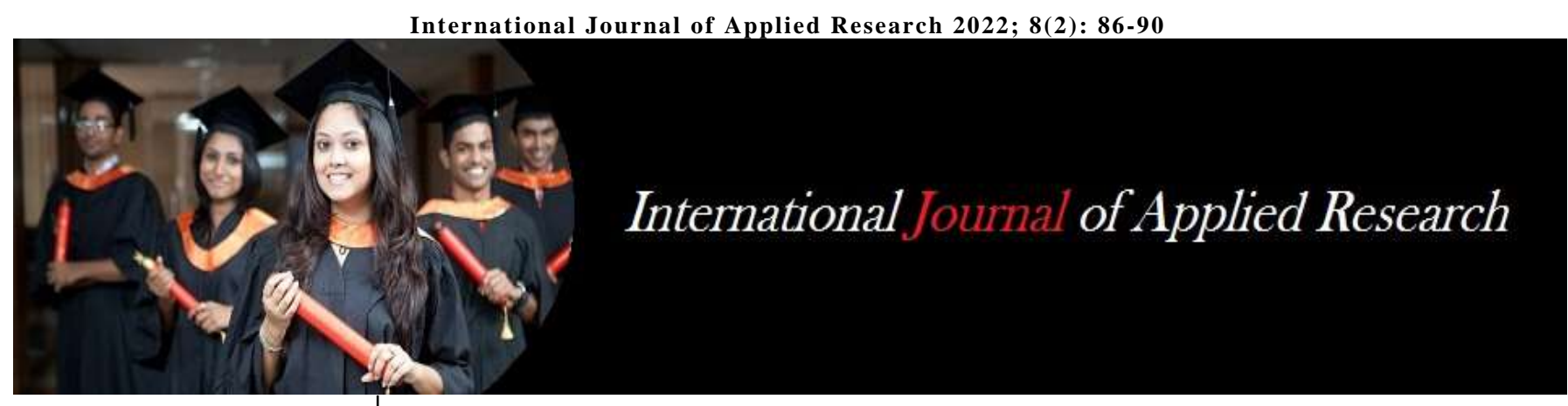

ISSN Print: 2394-7500

ISSN Online: 2394-5869

Impact Factor: 8.4

IJAR 2022; 8(2): 86-90

www.allresearchjournal.com

Received: 25-11-2021

Accepted: 07-01-2022

Sunita Tarai

School of Political Science,

Gangadhar Meher University,

Amruta Vihar, Sambalpur,

Odisha, India
Corresponding Author:

Sunita Tarai

School of Political Science, Gangadhar Meher University,

Amruta Vihar, Sambalpur,

Odisha, India

\title{
Approaches to human security
}

\section{Sunita Tarai}

DOI: https://doi.org/10.22271/allresearch.2022.v8.i2b.9392

\section{Abstract}

Traditionally the idea of "security" has been framed in neo-pragmatist terms, connecting with ensuring the regional trustworthiness and political power of countries. The 1994 report given by the UNDP moved the focal point of the worldwide talk on security. The productive conversation of normative and experimental issues connected with the new security idea made it soon a focal thought on the worldwide security plan. During the last decades the rise of a wide scope of new security threats at the nearby, local, national, and worldwide level, including risks connected with an ethnic violation and common conflicts, fierce radicalism, environmental change, illegal exchange. Human security indicates a multi-faceted and all-encompassing way to deal with security that depends on the conviction that issues like human rights, advancement of the individuals, and instability in struggle zones are firmly interrelated. This normative work analyzes the concept of human security and its implication in worldwide. This paper also discusses the different approaches to human security.

Keywords: Human security, trustworthy, conflict, violation, environmental change, illegal transformation

\section{Introduction}

The Human Development Report (HDR) of the UNDP in 1994 made a significant contribution to reshaping the international security agenda of the 'New World Order.' (Human Security Unit, 2016) ${ }^{[7]}$. The document outlined how the people-centered concept of 'human security' should replace the traditional focus on inter-state conflict, state border protection, and military solutions to security issues. Human security was considered as a comprehensive liberation concept that helps address many causes of human vulnerabilities around the world, including violent conflicts, deprivation of resources, human rights abuses, and environmental instability. Many observers of global politics express their views that the concept of human security promised a new normative order that could break free from the Cold War's ideological shackles and state-centric orientation (Homolar, 2015) ${ }^{[6]}$.

Despite ongoing debate about the meaning, scope, and usefulness of the concept, human security ideas have long been postponed, replacing traditional security governance that may empower and protect individuals. This should be the alternative to the security of human beings. Critics, on the other hand, have emphasized the concept's orthodox qualities and sought to raise awareness of the human security agenda's counterproductive practical outcomes. The shortcomings identified here include the universal claim to include and promote securitization, norms, power relations, and human security in everyday life (Homolar, 2015) ${ }^{[6]}$. As this study shows, the qualities of liberation commonly attributed to the concept of human security cannot simply be taken at face value. In this context, this article contributes to the discussion of different approaches to human security.

A few scholastic compositions regarding the matter have been also hazy. There are many works on human security issues relating to the UNDP report. Jorge Nef, for instance, devises a fivefold characterization conspire, contending that human security contains (1) ecological, individual, and actual security, (2) monetary security, (3) government-managed retirement, including "independence from separation in light old enough, orientation, nationality, or economic wellbeing," (4) political security, and (5) social security, or "the arrangement of mental directions of society equipped to saving and upgrading the capacity to control vulnerability and dread (Nef, 1999) ${ }^{[10]}$." 
Laura Reed and Majid Tehranian offer a rundown of human security's ten constituent components including mental security, which "relies on setting up conditions cultivating conscious, adoring, and compassionate relational relations," and correspondence security, or the significance of "opportunity and equilibrium in data streams (Tehranian, 1999) [11]." Other researchers keep away from the laundry list approach, yet offer similarly broad definitions. As indicated by Caroline Thomas, human security alludes to the arrangement of "fundamental material requirements" and the acknowledgment of "human respect," including "liberation from abusive power structures-be they worldwide, public, or neighborhood in beginning and extension (Thomas, 1999) [12]." For Robert Bedeski, human security incorporates "the entirety of the information, innovation, establishments and exercises that ensure, safeguard and save the natural presence of human existence; and the cycles which ensure and consummate aggregate harmony and thriving to upgrade human opportunity".

\section{Background and development of human security}

Human security is related to the more traditional concept of security, which is derived from the military analysis of the international affairs paradigm. While the dominant traditional security paradigm is based on anarchist relationships between nations, human security shifts the respected subject to the individual. Therefore, security threats include those that can threaten the integrity of a nation as well as those that can threaten the integrity of an individual. This opens up a much broader discussion of possible threats, but in doing so raises the question of conceptual clarity and practicality.

This concept was formally introduced into security discourse after the 1989 Cold War in response to threats beyond traditional security capabilities. The power balance has been effective in dealing with nuclear threats, but can it provide security from domestic conflicts, environmental disasters, hunger, illness, landmines, and domestic brutality.

Table 1: The major difference between the traditional approach to security and human security.

\begin{tabular}{|c|c|c|c|}
\hline Types of Security & Referent Object & Focus on the protection of & Possible threats \\
\hline Traditional Security & The State & The sovereignty and integrity of the state & Interstate war, nuclear proliferation, revolution, etc. \\
\hline Human Security & The Individual & The integrity of the individual & $\begin{array}{c}\text { Disease, poverty, natural disaster, violence, human } \\
\text { rights abuse, etc. }\end{array}$ \\
\hline
\end{tabular}

The first major statement concerning human security appeared in the 1994 Human Development Report, an annual publication of the United Nations Development Programme (UNDP). Economic, food, health, environmental, personal, community, and political security are the seven so-called dimensions of human security introduced by the UNDP Report. As the definition of the terms globalization and interdependence increased in the 1990s, the UN Security Council's interpretation practices for assessing threats or violations of international peace/security have changed.

The idea of human security is precisely based on this perception of interdependence. Ultimately, human security means a child who does not die, a disease that does not spread, a job that is not lost, ethnic tensions that do not turn violent, and a dissident who is not silenced." Human security is more than just about weapons; it's about human life and dignity." Importantly, the concept also implies a shift in perspective: whereas traditional security thinking focused primarily on the protection of the nation-state, the concept of human security is more expansive, arguing that the reference object should be the individual (UNDP, 1995) [1].

In contrast to these more pessimistic remarks, Martin and Owen (2010) believe that if the problem of weak conceptualization, which is particularly prevalent in the UN's traditional understanding of human security, is addressed, the second generation of human security could emerge. Nonetheless, the recently released Human Security Report "The Shrinking Costs of War" emphasizes that the concept remains urgent and relevant today. Surprisingly, the Report examines three interrelated developments that have been driving down conflict deaths for more than a decade (namely, the changing nature of warfare, global health policy that reduces deaths during peacetime and increased humanitarian assistance) (Human Security Report 2009: 7). This clearly demonstrates the intricate interconnectedness of various forms of threat to humans.

\section{Philosophical Roots}

Emma Rothschild gives a concise overview of the scholarly history of human security, dissecting that while this is a contemporary idea, its foundations can be found in a very long-term banter, from the Treaty of Westphalia (1648) to the Concert of Europe (1815). At its center, contends Emma Rothschild, Human Security is an equivalently disorderly contention for a re-visitation of illumination progressivism. It is just one of the numerous traditionalist questionings of the customary security worldview, one that still can't seem to completely characterize itself, not to mention rival a centuries-old discussion. To be sure, large numbers of the center standards of human security are unrefined impressions of Montesquieu, Rousseau, and Condoorcet, however so too are standards of state security established in erudite people of the time - Kant, Hobbes and De Grotius whose contradicting state-focused perspective seemingly beaten these more pluralistic convictions. Since the discussion over the connection among individual and state as the respectful object of safety isn't new, some remark on past points of view is valuable.

As Rothschild brings up, one side of the security discussion of the eighteenth Century is established in pluralist convictions targeting the security of human beings. For Montesquieu, this was a solitary spotlight on the opportunity and the apparent privileges of people over the directed security given by the state. Security for Adam Smith implied the assurance of the person from "unexpected or brutal assault with the rest of one's personal effects or property" (Ibid: 62). This security, he proceeds, is the main essential for a fruitful and "rich" society. Likewise, Condorcet depicted a cultural agreement wherein the security of the person was the focal guideline. Feeling of dread toward dread clarifies Shklar, was the central adversary to a liberal society (Shklar: 21). In the event that independence from dread was not ensured, then, at that point, people couldn't be powerful individuals from a political relationship.

This liberal point of view was far and wide, yet not consistent. Even though in arrangement over the crucial job 
of individual wellbeing, others accepted that this could best be accomplished as a result of the security of the state. The state, in this manner, goes about as a defender from both outer and inner dangers.

For Hobbes, it implied little whether man's frailty, 'single, poor, dreadful, brutish and short' was on account of a nearby cheat or an attacking armed force. Assurance from it is possible that, he accepted, was the outright obligation of the state. For this assurance, the resident should surrender all singular freedoms to his country, his defender. As seemingly the introduction of realism, Hobbes set forward a model of outright state command over the security of people security beating freedom (Hobbes, 1651). While additionally checking out the job of the state in giving individual security, Kant imagined a higher authority still. He proposed a universalist worldwide order, dependent fundamentally upon its ethical direction part countries, on a typical decent, a worldwide society. As a center ground between the two, De Grotius proposed a safer worldwide dynamic, one not directed by supranational law, be that as it may, by an overall influence among states. The shared interest of autonomous yet coinciding state substances, in this way, guarantees the security of all. Even though each led to an alternate school of international idea (Hobbes and authenticity, Kant and worldwide security, De Grotius and global security (Ibid: 7)), all based the essential obligation of ensuring individual security on account of the state. This would turn into the predominant perspective, ostensibly prevailing upon more liberal thinking, until the finish of the Cold War.

\section{Human Security Defined: From Broad to Narrow}

The human security idea, thusly, shifts the referent object of safety from the state to the person. This is vital because of the previously mentioned disappointments of the conventional security worldview, and to direct examination and strategy towards real issues undermining human beings lives.

As an overall depiction, (Rothschild, 1995: 55) portrays human security as one of four changing spots of safety. Starting with the state, she sees security being brought down to the person, up to the global framework or supranational actual climate, across from an emphasis on the military to incorporate the climate, society and economy, lastly, the obligation to guarantee security diffused every which way to incorporate nearby legislatures, peaceful accords, Ngo's, general assessment, powers of nature and the monetary market. Although not an unequivocal definition, this conceptualization gives an illustration of both how restricted the conventional worldview has been, just as how complex the development of the idea can turn into.

Albeit many endeavors have been made to all the more explicitly characterize what is an intrinsically vague idea (as it by definition envelops a possibly limitless rundown of danger), two reasonable ways of thinking have arisen in which most definitions can be gathered. These are the wide and tight, or, "freedom from need" and "freedom from dread", originations of human security.

\section{Broad Definition of Human Security}

Security, says Kofi Annan, "can at this point not be barely characterized as the shortfall of outfitted conflict, be it between or inside states. Gross maltreatments of common freedoms, the enormous scope uprooting of civilian populaces, global psychological warfare, the AIDS pandemic, medication and arms dealing and ecological calamities present an immediate danger to human security, driving us to take on a significantly more organized way to deal with a scope of issues (Annan, 2000) ${ }^{[4]}$."

The vast majority of the meanings of human security are established in the wide, or United Nations Development Program (UNDP), way of thinking. Despite the fact that pundits legitimately highlight a likely vagueness from gathering such countless dangers under one heading, theoretical clearness arises assuming three key ascribes are thought of; its extent of inclusion, its framework based way to deal with comprehension causal relationships, and its attention on the essential center of the person. These three basic parts of comprehensively characterized human security are exemplified by the (UNDP, 1995) ${ }^{[1]}$, Salbina Alkire and Jorge separately.

To begin with, the UNDP conceptualization sets up human security's expansive extension. The 1994 UNDP Human Development Report is for the most part considered to be the main critical effort to verbalize the wide way to deal with human security. This report depicts human security as having two head angles; independence from constant dangers like yearning, illness and constraint, combined with insurance from abrupt cataclysms. The report yields that it is expansive, however, clarifies that this is just an impression of the number of critical damages that go complete. As an applied construction, seven parts of human security the UNDP offers monetary, food, wellbeing, natural, individual, local area and political security (UNDP, 1995) ${ }^{[1]}$.

1. Economic security: the threat is poverty

2. Food security: the threat is hunger and famine

3. Health security: the threat is injury and disease

4. Environmental security: the threat is pollution, environmental degradation and resource depletion

5. Personal security: the threat includes various forms of violence

6. Community security: the threat is to the integrity of cultures

7. Political security: the threat is political repression. (Human Security Unit, 2016) ${ }^{[7]}$

What is important about this categorization is that it sets the "boundaries of the tent" very broadly, clearly separating itself from past security re-conceptualizations. Also, it forces other definitions of human security to justify their narrowing from this very broad starting point.

Second, Jorge Nef calls attention to the significance of a part-based way to deal with characterizing human security. (Nef, 1999) ${ }^{[10]}$ He depicts five interconnected subsystems of human security: biological system, economy, society, country, and culture. For Nef, these five are all in an intricate exchange, their linkages characterizing the idea of fundamental equilibrium. All the more roughly, this calls attention to that on the off chance that causality will be tended to, the framework limits should be set comprehensively to catch the conceivable huge factors as a whole. Affirmation of the interconnectedness of human security parts, in any case, characterized, is totally basic both to getting causality and appropriately tending to strategy.

A third huge quality of the expansive origination of human security is its attention on the indispensable center of the person. This is fundamental to isolate 'human security' from the human turn of events, a term that is more connected with 
prosperity than desperate crises. The emphasis on the person in human security can maybe be best shown by (Alkire, 2003) ${ }^{[3]}$, in the accompanying statement. "The goal of human security is to shield the fundamental center of all human lives in manners that improve human opportunities and human fulfillment". Key to this definition is the emphasis on all basic and inescapable dangers profoundly. Rather than giving a clothing rundown of dangers, she sets models, outperforming which, any issue turns into a danger to human security. She likewise assumes that even though organizations can't be anticipated to shield individuals from all hurts, they ought to at minimum location those that pointlessly take lives.

Considering these three ascribes, the wide origination of human security starts to explain. Concurring top proponents of this meaning of the human security term, it should be comprehensive, projecting a "wide tent", it should isolate its parts into various sorts of safety to address causality, and it should set an edge delineating the fundamental center to isolate itself from the human turn of events.

\section{Narrow Definition of Human Security}

On the opposite finish of the range tending to meanings of human security is the 'restricted', for sure has become known as the Canadian Approach. By utilizing a definition that centers around vicious dangers, the Canadian Approach obviously isolates human security from a lot more extensive and as of now settled field of worldwide turn of events. Without a doubt, the Canadian government recognizes the UNDP origination as simply a stage in the advancement of human security, however, imagines a considerably more engaged definition, one fixated on savage dangers, as an instrument of strategy.

The Canadian definition, along these lines, confines the boundaries of human security to attention on the danger of savagery to the person. This can emerge out of a huge range of dangers, including medication exchange, landmines, ethnic disagreement, state disappointment, dealing with little arms, and so forth.

The Human Security 2003, to be produced by the Human Security Center at the Liu Institute for the Study of Global Issues, University of British Columbia, and is modeled after the Human Development Report, also uses a narrowly defined understanding of human security, limiting its scope for pragmatic and methodological reasons. For instance, pragmatically, the Human Development Report already covers the freedom from the want side of the spectrum, so another such report would be redundant. Methodologically, understanding the relationship between underdevelopment and violence necessarily requires a separation of the dependent and independent variables.

Presently, the definition of human security given by UNDP in 1994 is widely quoted and formulation by the most authoritative member states in their particular interest. For example, as the view of the Japan Government, the concept of human security includes all measures that threaten the survival and daily life of human beings and human dignity such as human rights violation, environmental destruction, cross-border crimes, illegal drugs and refugees, poverty, and infectious diseases, etc (Japan, 1999) ${ }^{[8]}$.

\section{Approaches to human security}

A popular expression "human security", as a strong methodology focusing on the interrelatedness among neediness, basic liberties, and general wellbeing, instruction, and political association, has entered to public talk through the 1994 United Nations Development Programme (UNDP) report. It has been contended that a new and far-reaching way to deal with security thought was important to address sensitive compassionate difficulties in the post-Cold War climate. The operationalization of human security by submitted organizations in a manner that applies to their settings has normally brought about to some degree smaller understandings of human security.

For instance, Canada, Norway, and Japan have fused human security into their international strategy structures. Canada has accepted human security as the worldview for its international strategy and has played a position of authority in operationalizing it. Canada's international strategy structure has kept a particular spotlight on harmony, security, improvement, and worldwide participation all through the Cold War. The human security plan has offered a way for Canada to contribute "a main voice on the world stage." It was in the Ottawa Convention that the landmines deal was marked - something that Lloyd Axworthy, one of the energies behind Canada's human security center, portrayed as the "primary significant achievement" of the human security plan. By 2000, at the point when human security showed up on Canada's spending plan with devoted financing, Axworthy (who holds a more extensive meaning of human security) reports that Canada's security board utilized the language and idea of human security routinely: "On the plan were issues like ensuring regular folks in the equipped clash, transforming sanctions systems to moderate pessimistic helpful results, reinforcing the privileges of ladies in places like Afghanistan, and the need of compassionate mediation to ensure against a future Rwanda or Srebrenica." (Edström, 2003) ${ }^{[5]}$ Conceptually, Canada's translation of human security centers on "independence from inescapable dangers to individuals' freedoms, wellbeing or lives" - the insurance of regular people, struggle avoidance, public security, administration and responsibility, and harmony support activities. As Rob McRae summed up this translation, "At its most fundamental level, human security implies independence from dread." Canada's contention centered reformulation of the human security term saves destitution decrease objectives, yet this limited understanding is guarded, on the grounds that we accept this is the place where the idea of human security has the best worth-added - where it supplements existing worldwide plans currently focused on advancing public safety, common freedoms and human rights.

Norway in like manner centers on the independence from dread parts of human security and distinguishes a center plan of preventive activity, little arms and light weapons control, and harmonious operations. Both countries tracked down human security, with its accentuation on ensuring people, to be valuable in featuring new and fundamental parts of safety from brutal resistance. They in this manner established the Human Security Network (also called the Lysøen Group), whose yearly gatherings draw in NGOs and administrative entertainers from around 13 nations, including Austria, Canada, Chile, Greece, Ireland, Jordan, Mali, the Netherlands, Slovenia, Switzerland, Thailand. They have activated around reasonable reactions to human security dangers. The subjects of their activities incorporate "security for regular people," "landmines deal," a "extremely durable worldwide crook court," youngsters' issues (the discretionary convention to the Convention on the Rights of 
the Child on least ages for enlistment and organization of warriors), "little arms and light weapons," and "medication dealing and coordinated wrongdoing organizations."

Japan maintains the broadest definition of human security, which "comprehensively covers all the menaces that threaten human survival, daily life and dignity... and strengthens efforts to confront these threats."(Acharya, 2020) [20] Particularly, Japan does not prioritize "freedom from fear" over the "freedom from want", but holds them as dual objectives of human security (Acharya, 2020) [20]. According to Japan's "blue book," Japan emphasizes "'Human Security' from the perspective of strengthening efforts to cope with threats to human lives, livelihoods and dignity such as poverty, environmental degradation, illicit drugs, transnational organized crime, infectious diseases such as HIV/AIDS, the outflow of refugees and antipersonnel landmines, and has taken various initiatives in this context (Japan, 1999) ${ }^{[8]}$. To ensure 'Human freedom and potential,' a range of issues needs to be addressed from the perspective of 'Human Security,' focused on the individual, and requiring cooperation among the various actors in the international community, including governments, international organizations and civil society." Japan's Human Security emphasis has found leadership in the highest levels of government and supports both development-related activities and peace-related activities.

US international strategy, despite the fact that it announces responsibilities to world harmony and security, remains to act as an illustration of negative human security. US international strategy actually gives foremost significance to the customary state-driven idea of human security and attempted to ensure the interest of tight homegrown interest and authority while interceding in harmony process. US point of view to war casualties particularly from the Middle East is passionately scrutinized by Amnesty International. In the Baluchistan region of Pakistan, for instance, Amnesty International has recorded torment, conceivable extrajudicial executions, and other unlawful killings and vanishings. (Menon, 2007) [9]

\section{Conclusion}

The above-applied components of human security clarify that the idea is as yet advancing but to create as an undeniable strategy choice for the vast majority of the nations. There exist primary, social, and territorial imperatives for quite some time to fuse human security structure in the different policy processes. The approach can possibly alleviate worldwide poverty, ecological perils, really take a look at the spread of sicknesses and take part in harmony-building measures. For the very explanation that human security structure presents a huge takeoff from the past security system, significant increases could be acknowledged through policy drives. The system makes it conceivable to accomplish different targets through the comprehensive commitment of one approach region. In the present time of globalization, worldwide exchange, and combination, accomplishing human security requires consolidated exertion of government, common society associations, corporate and global establishments.

\section{References}

1. UNDP. Human Development Report. New York: Oxford University Press, 1995.
2. Acharya A. Human Security. In S. S. John Baylis, The Globalization of World Politics. United Kingdom: Oxford University Press, 2020, 449-462.

3. Alkire S. A Conceptual Framework for Human Security. University of Oxford: Centre for Research on Inequality, Human Security and Ethnicity, CRISE, 2003.

4. Annan K. Report of the Secretary-General on the Work of the Organization. New York: United Nations, 2000.

5. Edström B. Japan and the Challenge of Human Security. Singapore: Institute for Security and Development Policy, 2003.

6. Homolar A. Human security benchmarks: Governing human wellbeing at a distance. Review of International Studies 2015, 843-863.

7. Human Security Unit, U. N. Human Security Handbook: An integrated approach for the realization of the Sustainable Development Goals and the priority areas of the international community and the United Nations system. New York: United Nations, 2016.

8. Japan MO. Diplomatic Bluebook. Japan: Ministry of Foreign Affairs of Japan, 1999.

9. Menon S. Human security: Concept and practice. Munich Personal RePEc Archive, 2007, 3.

10. Nef J. Human Security and Mutual Vulnerability. Ottawa: International Development Research Centre, 1999.

11. Tehranian M. Worlds apart: Human security and global governance. New York: Toda Institute for Global Peace and Policy Research, 1999.

12. Thomas PW. Globalization, Human Security, and the African Experience. Boulder: Colo: Lynne Rienner Publishers, 1999.

13. Thomas, Wilkin P. Globalization, human security, and the African experience/edited by Caroline Thomas \& Peter Wilkin. Lynne Rienner Publishers, 1999. 